\title{
Jesuit Portraits of Protestant Missionary Activity in Southern Africa in the Nineteenth and Twentieth Centuries
}

\author{
Wilfred Sumani, s.J.
}

The interaction between Jesuits and Protestant missionaries in Africa, particularly in the Zambezi Mission, was more complex than is often assumed. While relations between the two missionary bodies are usually described as "bitter" or "rivalrous," and their approaches to missionary work as diametrically opposed, a more careful analysis suggests that this is an oversimplification. This chapter draws upon the writings of Jesuits who worked in southern Africa in the late nineteenth and early twentieth centuries with the aim of painting a more balanced picture of the Jesuit perception of Protestant missionary work in the region. As we will see, not all of the Jesuit missionaries' writings present the Protestants in the same light: while some Jesuits describe Protestant missionary activity in negative and antagonistic terms, others were much more positive. To make sense of these differences, the chapter identifies a range of factors that may have informed the opinions of the Jesuit authors who wrote about the Protestant missionaries, including their closeness to the Protestants (dialogue of life), their hands-on missionary experience (missionary wisdom), and the interests of those writing the reports (motivation). Overall, the chapter argues that Jesuits and Protestants faced the same challenges and suffered similar losses, anxieties, and frustrations in their missionary ventures.

\section{Brief Historical Background to the Jesuit Presence in Southern Africa}

The nineteenth century witnessed the "second coming" of Jesuit missionaries to southern Africa (extending, for the most part, to present-day South Africa, Zimbabwe, and Zambia). Two centuries earlier, the Portuguese Jesuit Gonçalo da Silveira (1526-61) had sacrificed his life in the then Monomotapa Kingdom, earning himself the title of the "proto-martyr" of southern Africa. However, by the time Jesuits returned to Africa in the nineteenth century, Protestant missionaries had already crisscrossed the continent, especially the southern 
part, establishing a number of mission stations in their wake. Georg Schmidt (1709-85), of the Moravian Church, who was the first Protestant missionary to arrive in South Africa in 1737, established a mission among the Khoikhoi. Other Protestants arrived in southern Africa and established mission stations in the interior a few decades later. Dr. Robert Moffat (1795-1883) opened a mission station at Kuruman (seven hundred miles from Cape Town) in 1810, thirty years before David Livingstone's (1813-73) visit to the area. Livingstone, a representative of the London Missionary Society (LMS), reached the Great Lakes in 1866. By 1870, another LMS missionary, John Boden Thomson (1841-78), had established a mission at Hope Fountain in present-day southern Zimbabwe, ${ }^{1}$ and Reverend Thomas Morgan Thomas (1828-84), also of the LMS, had established a mission in Matabeleland.

The Society of Jesus was initially reluctant to engage in missionary work in southern Africa. When they eventually arrived in the region to establish St. Aidan's College at Grahamstown in the Eastern Cape Province (South Africa), the general consensus was that they had arrived too late. In the words of Alfred Weld, s.J. (1823-90):

Not only has the region which lies south of the river been traversed in all directions; not only is it travelled over annually by trading and hunting parties; but for many years past, we grieve to say it, Protestant missionaries have been peaceably pursuing their avocation in the heart of this vast district. Wesleyans, Presbyterians, and London missionary agents have for years resided with security in the land which we seem to be only now discovering to be a field ripe for the Gospel. The truth is, we are too late. ${ }^{2}$

The Protestant churches had acquired vast tracts of land and created mission territories for which they held exclusive evangelization rights. The Jesuits thus found themselves obliged to go into the interior of southern Africa to scout for "virgin soil" not yet exposed to the influences of Protestants, Muslims, and white traders. Plans to advance to Lake Nyasa were abandoned because of the likelihood of competition from the Free Church Mission, which had already established itself in the area. ${ }^{3}$ The Jesuits also failed to establish a mission at

1 Iris Clinton, Hope Fountain Story (Bulawayo: Mambo Press, 1969), 13-14.

2 Alfred Weld, Mission of the Zambezi (London: Burns and Oates, 1879), 34.

3 In fact, when Bishop James Ricards (1828-93) wrote to Fr. Weld asking the Jesuits to open a Jesuit mission in southern Africa, Ricards had in mind the area of Lake Nyasa (present-day Malawi). Weld initially thought it was a good idea, especially given that some slaves from the neighborhood of Lake Malawi had been rescued in a Catholic orphanage in Bombay and 
Shoshong (in present-day Botswana) due to the refusal of Khama III, chief of the Mangwato (c.1837-1923, r.1872-73, 1875-1923), to welcome them in his territory. The LMS had already established itself in this area and, in the king's estimation, there was no need for more "teachers"; 4 the king also warned the Jesuits that, though the Protestants had worked in the territory for more than twenty years, they had not enjoyed much success because the people were not disposed to Christianity. ${ }^{5}$

The Jesuits in southern Africa interacted with Protestants at various levels, as can be seen in the remarks made about Protestants in the diaries or articles of the Jesuit missionaries who worked in the Zambezi Mission. Some of the remarks about Protestants are positive, while others are disparaging, and they need to be read in their broader context.

\section{Casting a Shadow on Protestant Missionary Work}

\section{Richard Sykes, s.J.}

Richard Sykes, S.J. (1854-1920) was among the Jesuits who commented on the Protestant presence in southern Africa. Born in Lancashire, Sykes joined the Society of Jesus at Roehampton in 1874 and was ordained on September 25, 1887. In 1896, after serving as prefect-general and rector of St. Francis Xavier in Liverpool, he was appointed superior of the Zambezi Mission. He later became prefect apostolic of the same mission. In 1904, he was named provincial of the Society's English province. After his mandate, he returned to South Africa, where he died in 1920.6

Sykes wrote a number of articles about Protestant missionary activity in Africa. In one of his articles, published in the inaugural issue of the Zambesi

were willing to return to Malawi and bring Christianity to their fellow Africans. These, Weld thought, would make good interpreters. However, the idea was eventually dropped because the area was already occupied by the Free Church Mission. See Anthony J. Dachs and William F. Rea, The Catholic Church and Zimbabwe (Gwelo: Mambo Press, 1979), 17.

4 See Rob S. Burrett, "The Zambezi Mission and the Residences of Good Hope and Immaculate Heart of Mary, Old Tati," Botswana Notes and Records 32 (2000): 25-38, here 27-28. Chief Khama, who was converted to Christianity by the London Missionary Society, is said to have been a "deeply committed Christian known for his uprightness." Edward P. Murphy, s.J., "First Zambesi Mission," in A History of the Jesuits in Zambia: A Mission Becomes a Province, ed. Edward P. Murphy, S.J. (Nairobi: Paulines Publications Africa, 2003), 6o-86, here 68.

5 See Henri Depelchin, "From Tati to Gu-Bulawayo," in Diaries of the Jesuit Missionaries at Bulawayo 1879-1881, Rhodesiana Society 4 (Bulawayo: Mardon Printers, 1974), 9-16, here 15.

6 “Obituary, Fr. Richard Sykes, s.J.," Tablet (May 15, 1920): 15. 
Mission Record (ZMR) in March 1898, Sykes claimed that the Protestants had been able to outpace the Catholics in evangelizing African peoples partly due to generous financial donations from Protestant communities in Europe and America. Citing the Times for January 15, 1897, he notes that in "the past year the total income of the Protestant Missionary Societies throughout the world

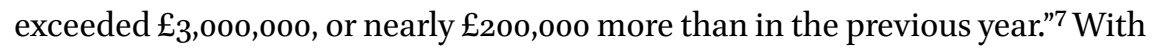
their huge sums of money, Protestants

are thus enabled to purchase large tracts of land, to which they have exclusive right in law, and on which therefore no Catholic missioner can settle without their sanction [...]. They can prejudice the natives for miles and miles round against Christianity and render it difficult work for the Catholic missioner to make headway amongst them. ${ }^{8}$

Sykes viewed this as unacceptable because the Protestants were teaching a "mutilated form of Christianity" based on "inconsistent doctrines" that were sure to bring Christianity into ridicule, thereby making it difficult for Catholics to preach the "truth." In his view, even though they claimed to be Christian, Protestant churches were "religions of human origin"9 that lacked claim to universality.

On the contrary, Sykes subscribed to the imperialistic vision of Catholicism and challenged Englishmen not to be "Little Englanders" but to "look with pride upon a Greater Britain beyond the seas and upon an empire upon which

7 This Protestant generosity stood in stark contrast to what he viewed as the miserliness of Catholics, with Sykes claiming that Catholics throughout the world had only managed to contribute around $£ 250,000$ to missionary work in Africa during the same period.

8 Richard Sykes, "Protestant Missionary Activity in South and Central Africa," Zambezi Mission Record [hereafter ZMR] 1, no. 1 (1898): 11-15, here 13. Sykes makes a similar point in another contribution to the journal. While thanking benefactors for their contributions to missionary activity in the world, he reminds all to take into consideration that these contributions compare "only unfavorably with the immense sums given for the conversion of the heathen by the Protestant bodies, especially of the United States and England." Richard Sykes, "The Missioner's Debt," ZMR 5, no. 63 (1914): 15-19, here 17-18. Bishop Anthony Gaughran, O.M.I (1849-1901), then vicar of the Orange Free State, also attests to the strained relationships between Catholics and Protestants. In an interview accorded to The Tablet, he reports that, in Griqualand, Catholic missionaries attracted a following among the local people and began to instruct the natives. However, Calvinists, who had been in the country since 1833 , came and opposed the work of the Catholics. The opposition resulted in the loss of enthusiasm on the part of the natives; see "An Interview with a South African Bishop," Tablet (September 22, 1888): 26.

9 See Sykes, "Protestant Missionary Activity," 14. 
the sun never sets."10 The metaphor of the "Greater Britain" was thus transposed onto the universality of the Catholic Church in an effort to draw more donations from Catholics in England. An article in The Tablet later approvingly cited Sykes's imperialistic outlook of the Catholic Church to invite Catholics to be more generous and ambitious in their missionary work in order to make the church more truly universal. ${ }^{11}$

Sykes also criticized the Protestant approach to evangelization, arguing that Protestants concentrated on the mental development of the natives to the prejudice of their practical formation. He claimed that intellectual formation had corrupted the natives and made them more vain and dishonest. An educated black person who lost his or her former simplicity became "insupportable, disobedient, contemptuous of others, even of his superiors, and oftentimes, when trained in the tenets of certain sects, smug and sanctimonious." ${ }^{12}$ An African educated by Protestants, according to Sykes, was also prone to exaggerating his rights and claiming equality with the white man. Sykes's recommendation was that "the native should be taught to use his hands not so much pari passu with his head, but he should be educated by and through his hands [...]. The native should be taught some useful and fairly laborious trade."13

In addition to corrupting the native peoples, Sykes claimed that the work of the Protestant missionaries had actually achieved very little in terms of producing converts; and even when Protestants managed to convert someone, the convert's way of life became worse than it was before his or her conversion. ${ }^{14}$ Those who converted to Protestantism seemed to inherit a "double dose of original sin," losing their African virtues while simultaneously assimilating the vices of the white people. Native vices such as thievery, lying, drunkenness, unchaste behavior, and laziness were only exacerbated by conversion to Protestantism..$^{15}$

In his article, Sykes paints a picture of Rhodesia before the arrival of Jesuit missionaries as a land steeped in the darkness of superstition, with no knowledge of divine teaching, "where the Commandments of God have never been

\footnotetext{
10 Ibid., 15 .

11 See "A Plea for Imperialism: Fr. R. Sykes, S.J. and Missionary Work," Tablet (April 10, 1909): 26.

12 Sykes, "Protestant Missionary Activity," 11.

13 Ibid.

14 One cannot help but remember Jesus's indictment against the Scribes and the Pharisees: "Woe to you, teachers of the law and Pharisees, you hypocrites! You travel over land and sea to win a single convert, and when you have succeeded, you make them twice as much a child of hell as you are" (Matt. 23:15).

15 See Sykes, "Protestant Missionary Activity," 11.
} 
explained to the people; where there is no external sign of the true God, no Church, no Cross, no Blessed Sacrament; which is delivered over to mere naturalism, unabashed, and unaided by any elevating or spiritualizing influences."16 This was the state of the land found by the Jesuits, one "unlit by any ray of Christianity except here and there an infrequent non-Catholic Christian Mission Station just established, but which had not had sufficient time to spread any civilizing or Christianizing influence around."17 In other words, according to Sykes, Protestantism had done little or nothing in terms of evangelization by the time Jesuits arrived in the area. ${ }^{18}$

Sykes expressed similar opinions in his comments on the Kikuyu Conference, an interdenominational meeting held at the Church of Scotland's parish in Kikuyu (in present-day Kenya) in June $1913 .{ }^{19}$ The conference's purported aim was to heal divisions among Protestant denominations working in British East Africa (today's Kenya), Uganda, and Zanzibar, on the one hand, and, on the other, to explore ways of enhancing greater collaboration among Protestant churches in the region. However, Sykes maintained that the conference's real purpose was to create a united front for Protestants against the "solid phalanx of Catholicism and the aggressive cohesion of Mohammedanism." He was convinced that Protestantism was a "disruptive force," a movement that was essentially fissiparous and centrifugal. The attempt to unite various denominations, which he calls "sects," was therefore bound to fail.

It was futile, Sykes argued, to forge unity in accidentals (that is, non-doctrinal matters) while divisions remained in the realm of essentials (doctrine). Sykes's view is partly vindicated by the fact that not all non-Catholic churches were in favor of admitting to the pulpit ministers from other churches or the proposal of giving Communion to members of other denominations should the latter

16 Richard Sykes, “On Creating a Religious Atmosphere," ZMR 5, no.70 (1915): 272-76, here 273 .

17 Ibid.

18 A similar opinion is expressed by an anonymous author of an obituary for Fr. Peter Prestage, S.J. (1842-1907). In his glowing praise of the success of Prestage in evangelizing African peoples, the author writes, "Compared with the noise and fame which have surrounded the careers of such Protestant South African missionaries as the missionaryexplorer, Livingstone, or Moffat, or even of later representatives like Coillard and Steward, the humble and comparatively unknown career of a missioner like Father Prestage seems tame; but it reaches the loftiest heights of human effort in its enduring tenacity and in its heroic quality, if not in its picturesque adventurousness"; see "The Late Father Peter Prestage, S.J.," Tablet (May 4, 1907): 15 .

19 See Richard Sykes, "The Kikuyu from a Missionary's Point of View," ZMR 5, no. 65 (1914): 99-102. 
travel to an area where their ecclesial communities did not exist. Theologian Norman Powell Williams (1883-1943), for instance, argued that there was an essential difference between the Church of England and other denominations, for the former believed in the episcopacy as an essential element of the church's self-understanding. It was, therefore, inconsistent to allow ministers not duly ordained to preach in Anglican churches. ${ }^{20}$ Sykes claimed that the divisions and quarrels among Protestants had obliged civil authorities to parcel out territories to various denominations, compromising the unity of the Christian faith while making it difficult for Catholicism to realize its mission of preaching the Gospel to all peoples.

\section{Alfred Weld, s.J.}

Similar sentiments were aired by Alfred Weld, who succeeded Henri Depelchin, S.J. (1822-1900) as superior of the Zambezi Mission in 1883. Weld is credited with formulating a master plan for the Zambezi Mission. In his contribution to The Tablet of December 31, 1887, he describes the work of Protestants such as the Lutherans, noting that the Bechuana (the local inhabitants) had not yet heard the Gospel of Truth even though the Protestant missionaries had been there for over sixty years: "The neighborhood is alive with Lutheran and other sectarian ministers, who seem to have produced little other influence on these corrupt polygamists than prejudice against the Church."21

With regard to the education of the natives, Weld concurred with Sykes's idea that Africans deserved to be taught useful and laborious trade as opposed to the Protestants' alleged emphasis on mental development. His article indicates how the Jesuits prioritized technical or practical education interspersed with religious education. At Dunbrody (Eastern Cape), for instance, the Jesuits acquired some land formerly belonging to the Trappists, and a religious community was set up on the property where African children were "taught to gain an honest livelihood, and instructed in the elements of education and the precepts of doctrines of the Catholic faith." ${ }^{22}$ Boys were taught agricultural skills, carpentry, shoemaking, and tailoring, among other trades, while girls were trained to wash, sew, knit, and other duties proper to domestic servants.

Before the Jesuits asked the king of the Mangwato for permission to evangelize the natives, Weld had expressed optimism that the African king would be enlightened by the Spirit and welcome the Jesuit missionaries:

\footnotetext{
20 See Norman Powell Williams, The Kikuyu Opinion (London: Longmans, Green and Co., 1915), 1-24.

21 Alfred Weld, s.J., "From the Dark Continent," Tablet (December 31, 1887): 35.

22 Ibid.
} 
It has been said that the Bamanguato tribe are already infected with Protestantism. The chief is a warm supporter of the sect. They are Protestants because they have never known the Catholic faith. Within a few weeks the missioners will present themselves before this man, who has the character of being the justest and most sincere of all the native chiefs in South Africa. If the Holy Spirit will vouchsafe to enlighten his mind, and show him that the Catholic missioners are the bearers of the true doctrine of Jesus Christ, and that what he has hitherto known is only a maimed and disturbed fragment of the truth, the whole tribe may be led to the faith at a stroke. ${ }^{23}$

Thus, for Weld, it was the Jesuits (Catholics) who were the bearers of the true faith. Weld even begrudged the title of "missionary" to the Protestants and simply regarded Livingstone as "the great traveller." ${ }^{24} \mathrm{He}$ also calls Protestant missionaries "ministers of error," sowing seeds of dissension and confusion among the natives. ${ }^{25}$

\section{Appraising the Negative Portrait of Protestant Missionary Work}

There is undoubtedly a grain of truth in what Weld and Sykes say about nineteenth- and twentieth-century Protestant missionary activity in southern Africa, for others beyond the Society of Jesus held similar views. Nonetheless, the failures of the Protestant missionaries would appear to be a common phenomenon extending well beyond the Protestant churches.

One reason for this was the lack of interdenominational cooperation. Most likely inspired by the colonial model, most of the Christian churches in Africa had resorted to the occupation of tracts of land, which became "mini-colonies." The Jesuits, for instance, had acquired land in Chishawasha (Zimbabwe), Chikuni, and Kasisi (both in Zambia), yet the natives who came to live on the land were only able to do so if they met a number of conditions, one of which was that they would send their children to the mission school. ${ }^{26}$

\footnotetext{
23 Weld, Mission of the Zambezi, 54-55.

24 Ibid., $36,38$.

25 Ibid., 35 .

26 See "Chishawasha Mission," Tablet (January 16, 1909): 27; Francis Richartz, "History of Chishawasha," in Early Days of the Jesuit Zambesi Mission, 1880-19oo: Accounts by John Weisskopf and Francis Richartz, ed. Edward Murphy (Harare: Jesuit Province of Zimbabwe-Mozambique, 2015), 77-135, here 91.
} 
There is no evidence that Protestant missionaries were allowed access to the African communities hosted on Catholic settlements. The Jesuits wanted virgin soil in which to plant the seed of the Catholic faith and did not want any "weeds" of adulterated faith to choke the plant of faith. Even in the twentieth century, Catholics were generally opposed to mixing with Protestants. In Northern Rhodesia (today's Zambia), for example, Protestants advocated interdenominational schools, which Catholics found unacceptable, instead preferring "Catholic schools for Catholic children under Catholic management."27

Moreover, regardless of the respective methods they used in their evangelization work, both Catholic and Protestant missionaries were faced with similar challenges in winning and retaining African converts. One of the lessons Weld learned from his few years in Africa was that "the real conversion of the black races, and even of one section of them, is a work of time, not to be achieved by spasmodic or isolated missionary enterprise, but by a continued effort on a carefully conceived plan." ${ }^{28}$ Missionary work, he observed, was compounded by difficulties of language, the caprice and avarice of local chiefs, and inadequate logistical support, among other issues. In the words of John Weisskopf (1848-83), a Jesuit stationed at Pandamatenga (northwest district of Botswana), converting the local people had proven so difficult that success would require God's miraculous intervention. ${ }^{29}$

A further problem affecting the missionaries was related to the native peoples' long-established cultural practices and beliefs. Writing in his diary, the Belgian Jesuit Charles Croonenbergh (1843-99) reported that the missionaries had failed to achieve a great deal among the Ndebele because of their reluctance to abandon the custom of polygamy. ${ }^{30}$ Another obstacle was what he called superstition, consisting in belief in witchcraft. As a result, Croonenbergh was less judgmental when writing about the failure of such missionaries as Moffat and Thomas among the Matabele.

In Croonenbergh's estimation, the Matabele were materialists who had no interest in spiritual goods. While they were eager to receive the missionaries' brandy, calico, and beads, they were not interested in the Gospel. He further describes the Matabele as "a people given over completely to idleness, drowned

27 Brendan Carmody, Conversion and Jesuit Schooling in Zambia (Leiden: Brill, 1992), 81-82.

28 Weld, "From the Dark Continent," 35.

29 John Weisskopf, "Along the Zambezi: 25 June to 19 November 1880," in Murphy, Early Days of the Jesuit Zambesi Mission, 29-72, here 49.

30 See Charles Croonenbergh, "Matabele Customs," in Diaries of the Jesuit Missionaries at Bulawayo, 23-25, here 23 . 
in laziness and in all its allied disorders, having practically no conception of divinity, no notion of justice or injustice, and all of whose institutions and customs are diametrically opposed to the teachings of the Gospel."31 Francis Berghegge, s.J. (1849-1916) had a similar view of the people of Mambova, who, despite their affability, seemed to find greatest happiness in food and beer. ${ }^{32}$

Thus it is clear that the lack of African converts could not be blamed squarely on Protestant ineptitude. The problem was not necessarily in the approach of the Protestant missionaries; the difficulty was that the worldview of the African peoples did not tally with the Christian message as preached by European missionaries, whether Catholic or Protestant. The Ndebele, for instance, had their own repertoire of religious rituals that helped them to address the day-to-day challenges facing the community. ${ }^{33}$ Though Croonenbergh doubted the "religiosity" of these ceremonies, the fact remains that the local peoples were convinced that their religion did not need to be replaced with another. Indeed, some Africans regarded the missionaries as a people without a religion, for the Europeans did not seem to hold religious services. ${ }^{34}$

Having understood how secondary, if irrelevant, the Gospel appeared to be for the natives, the Jesuits devoted their early years in Matabeleland responding to the material and practical needs of the local people. Croonenbergh himself spent much of his time providing medical services to the people. As a result, despite spending an entire year in Matabeleland, Jesuits could only report the baptism of a leper ostracized by the community. ${ }^{35}$

The Ignatian principle of entering through the people's door in order to exit through one's own was of critical importance in the Jesuits' interactions with the African peoples. Francis Richartz, S.J. (1854-1928) concedes that, at Chishawasha, evangelization

was a work that required a good deal of patience because there were hardly any signs of success or interest in our lessons. While a person longs for happiness he finds it in food and drink. It will be a long time before he will appreciate the homily and this is the cross of the missionary.

31 Charles Croonenbergh, "A Letter from Father Croonenbergh," in Diaries of the Jesuit Missionaries at Bulawayo, 30-33, here 31.

32 See Fien Berghegge, "Account of a Journey in Central Africa," Rhodesiana 3 (1958): 1-13, here 5 .

33 See Charles Croonenbergh, "The King Makes Rain," in Diaries of the Jesuit Missionaries at Bulawayo, 61-65, here 61-63.

34 See Berghegge, "Account of a Journey in Central Africa," 6.

35 See Charles Croonenbergh, "Visit of the Queens," in Diaries of the Jesuit Missionaries at Bulawayo, 59, 62 . 
He has to use all means and tricks patiently to enter in through the door of the people, so as to leave by his own door. The missionary must be aware from the very beginning that it will not be a quick victory. ${ }^{36}$

Catholics, like Protestants, also experienced the challenge of keeping converts true to the faith. This difficulty was acknowledged by a Jesuit missionary working in the Zambezi Mission. After sharing the good news that the number of baptized Africans had reached 1,734, the Jesuit admitted that the more challenging task was to "keep what we have won, to preserve the converted native in the practice of Catholicity. This is indeed the great problem of all missionaries in Africa. It is almost more difficult to keep the native true to the faith than to win him to the faith." ${ }^{37}$ One of the factors contributing to the loss of converts was the high mobility rate among Africans. Their departure from one area to another in search of work often entailed their departure from the faith they had embraced. The introduction of Christian villages was, in fact, meant to mitigate the relapse of African converts into "heathenism."38 To criticize Protestant missionary work on the basis of its products is thus to be blind to dynamics beyond the control of any missionary. ${ }^{39}$

Croonenbergh was also aware that the African situation was not unique in the history of evangelization. It had been equally difficult to evangelize the Saxons of Germania and the "cannibals" of Oceania. With a sober grasp of what some scholars would call "anthropological constants," he affirms that

humanity is everywhere the same, and, where Christianity does not exist, the same aberrations exist in all parts of the world. It would be a most interesting study to make a research into the analogies which exist

$36 \quad$ Richartz, "History of Chishawasha," 93.

37 "Progress in the Mission during 1913," ZMR 5, no. 64 (1914): 58-6o, here 59.

38 Dachs and Rea, Catholic Church and Zimbabwe, 6.

39 In fact, elsewhere, Jesuits have similarly been unfairly judged by Protestants. The anonymous author (signed simply as "K") of the article "The Pope and Romish Missions" gratuitously accuses Jesuits of planting the wrong faith in Asia and in Latin America, a faith that conformed to the traditions of the local people and revolved around rituals and devotions (sensuous religion), rather than a true appreciation of the Gospel. In their work of evangelization, the author continues, Jesuits accumulated and made use of immense earthly goods, all the while professing evangelical poverty. See "The Pope and Romish Missions," Church Missionary Intelligencer and Record (October 1886): 721-35; "On the Character of Jesuit Missionary Teaching," Church Missionary Intelligencer and Record (July 1886): 529-45. These accusations, like the ones made by Jesuits against Protestants, would lose their force when evaluated in a broader context. 
between the superstitions of our Matabele and those of the ancient pagan people of Italy, of Greece, of Syria and of Egypt. ${ }^{40}$

As we saw above, Sykes expressed disapproval of the Protestant approach to the education of the natives, arguing that Protestants wrongly focused on mental education instead of empowering the Africans with practical (manual) skills. But time would be a better judge. Indeed, by 1914, the more informed view was in favor of the integral education of the Africans. The editorial for the sixty-third issue of the $Z M R$ attests to the shift in public opinion:

It is true that we still meet people in this land who maintain that it is sheer waste of time and energy to give schooling to the blacks, and that the "raw," i.e., the uncivilized and uneducated, native is in every way superior to the product of the mission schools. But persons who say this speak without reflection and without any acquaintance with the subject. They have absolutely no knowledge of the good which is effected in the souls and minds of the natives by the teaching of the missionaries, and their deep-rooted hostility to the religious and literary training of the blacks is in most cases based on a few instances of hypocrisy, sloth or vice on the part of educated natives, which have come to their notice or about which they have heard. They quite ignore the fact that the almost unanimous verdict of those who have thoroughly and impartially investigated the subject is against them. ${ }^{41}$

The editorial speaks not only of "religious training" but also of "literary training." The self-definition in the editorial is not "Catholic" as opposed to "Protestant," but rather the common tag of "Christian missionaries." Protestants and Catholics found themselves united in a common cause, and their common quest was to persuade the colonial government to leave the education of the natives to religious bodies, though the government would have to provide some requisite funding. The missionaries wanted to have exclusive rights to the intellectual, religious, moral, and technical formation of the Africans.

It would appear that Sykes's opinion was partly informed by the view that the vocation of Africans was limited to the execution of menial tasks, often at the service of white people. In fact, the importance of an educated African was already clear in the early twentieth century when the colonial government

40 Charles Croonenbergh, "Justice and Religion under Lobengula," in Diaries of the Jesuit Missionaries at Bulawayo, 47-50, here 48.

“Editorial," ZMR 5, no. 63 (1914): 3-5, here 4. 
in Northern Rhodesia would sometimes hire skilled Africans from Nyasaland (who had received an education in Protestant schools) to serve as clerks, among other jobs. It is also reported that Africans in Northern Rhodesia who had the financial resources to do so would send their children to boarding schools in Nyasaland and Southern Rhodesia. Later, the Free Church of Scotland working among the Bemba adopted the education policy of Protestant churches in Nyasaland, just as the Primitive Methodists serving among the Tonga "believed that Africans had the potential to develop intelligence equal to Europeans." ${ }^{22}$ The first two teachers' training centers in Northern Rhodesia were set up by the Primitive Methodists at Kafue and the Paris Evangelical Mission at Sefula. ${ }^{43}$ The contribution of these centers to the education of the local population cannot be overemphasized.

Sykes opposed the mental formation of Africans, instead calling for the development of their technical skills. However, as more and more Africans acquired technical skills, some European artisans expressed their opposition to the industrial training of the natives, because European artisans, being more expensive than Africans, risked losing job opportunities. Consequently, some Europeans advocated limited industrial training of Africans so that they would remain assistants of white artisans. The Jesuits apparently supported the position of the colonial government, namely that individual Africans should be given as much technical training as their capacity could muster rather than setting an upper limit to the technical education they could receive. In the words of an editorial in the $Z M R$ :

Why, for instance, should an intelligent native boy, who shows an aptitude for bricklaying, stonemasonry or carpentry, be debarred from receiving instruction in these trades because he may, if taught them, become a competitor of the European workman? [...]. How much the whole country would have benefited; how many buildings at present non-existent would have been erected if cheap skilled native labor had been available! ${ }^{44}$

The divisions on this issue were ultimately about the interests of those involved in this debate and the role they envisaged for native Africans in wider society. Thus, whereas some missionaries believed it was preferable for native 131.

43 Ibid., 130.

44 "Editorial," ZMR 5, no. 66 (1914): 117-19, here 118.
} 
Africans to receive technical training rather than mental formation because they viewed Africans as servants of the European settlers, white artisans opposed a high-level of technical training for the natives because they stood to lose jobs to Africans regarded as cheaper labor. Prospective employers, on the other hand, held to the view that native African artisans should receive the highest level of technical training because they would be able to save costs by hiring trained Africans. The question was not simply about mental or technical formation, in short, but what and whose interest such an education fostered or jeopardized.

\section{The Brighter Side of Jesuit-Protestant Cooperation}

In contrast to the views outlined above, a number of other reports written by Jesuits paint a more positive picture of the Protestant missionaries deployed in southern Africa and beyond. Though these reports do not necessarily speak about the successes of the Protestant missionaries, they do show that Protestants were not sworn enemies of Catholicism; rather, they were willing to share life (commune) with Catholic missionaries. These positive accounts emanate from contexts where Jesuits shared life with Protestants. General Congregation 34 of the Jesuits would later call this the "dialogue of life, where people strive to live in an open and neighborly spirit, sharing their joys and sorrows, their human problems and preoccupations." 45

\section{Jesuits in Praise of Protestant Hospitality}

As we have seen, the Jesuit return to Africa in the nineteenth century was preceded by the arrival of various Protestant missionaries who established themselves in different parts of southern Africa. A number of Jesuits gratefully recalled how Protestants accorded them hospitality as the new arrivals struggled to find their feet on the ground. In his letter to the editor of The Tablet, Weld recalls how, at Kimberley, "Protestants vied with Catholics in rendering them [the Jesuits] service." 46

Similarly, the Jesuits at Gubulawayo (present-day Zimbabwe) waxed lyrical about the kindness they received from the Protestants there. Without any

45 General Congregation 34, decree 5, no. 4: "Our Mission and Interreligious Dialogue," in Jesuit Life \& Mission Today: The Decrees \& Accompanying Documents of 31st-35th General Congregations of the Society of Jesus, ed. John W. Padberg (St. Louis: Institute of Jesuit Sources, 2009), 547-56 here 548 .

46 Alfred Weld, "Mission of the Zambesi," Tablet (February 14, 1880): 22. 
knowledge of the locallanguage, the Jesuits relied on the help of their Protestant counterparts to conduct diplomatic transactions with the king and ordinary intercourse with the local population. In one of his diary entries, Depelchin writes, "We have had a long talk with the Protestant ministers: these gentlemen have treated us with the greatest courtesy." 47 Croonenbergh makes a similar point and names the Protestants in question: "Mr. Fairbairn and Mr. Martin, English Protestant gentlemen who live here [...] have done us a great service. [...] I am enjoying the kind hospitality of Mr. Martin who treats me like a son, indeed like a spoilt child." 48 When Croonenbergh was ill, it was Martin who looked after him. Understandably, he calls Martin "our benefactor."49

As they shared life together, the prejudices between the Jesuits and the Protestants began to dissipate. In Croonenbergh's words: "With the Protestant ministers, too, despite the difference of our religious beliefs, we have the most cordial relationships. Meeting as we do, in close intimacy, many prejudices vanish, many misapprehensions disappear. Recently, all the Protestant Missionaries, five in number, met at our house. 50

\section{Collaboration}

Jesuits acknowledged the Protestants' spirit of collaboration. Because of their proficiency in the local language and the influence they exercised over Lobengula, king of the Ndebele (c.1840-94, r.1870-94), Protestant ministers helped the Jesuits at Gubulawayo to win the king's acceptance and friendship. Martin often accompanied the Jesuits to the king's court and spoke in favor of the Jesuits. Charles Daniel Helm (1844-1915), an LMs missionary at Hope Fountain, also accompanied Croonenbergh to the king's court and introduced the Jesuit as a recently arrived $m$ fundisi (teacher) of Gubulawayo. Despite religious differences, Helm did not begrudge sharing the title mfundisi with the Jesuit. He was clearly a tolerant man, for, when the Jesuit explained to Lobengula why Catholic missionaries did not have wives, Helm, "a most excellent paterfamilias, not quite knowing how to keep himself in countenance, cloaked himself in a great cloud of smoke, and pulled upon his pipe with exceeding vigor."51

47 Henri Depelchin, s.J., "King Lobengula," in Diaries of the Jesuit Missionaries at Bulawayo, 16-18, here 17.

48 Charles Croonenbergh, "Father Croonenbergh's Account," in Diaries of the Jesuit Missionaries at Bulawayo, 21-23, here 22.

49 See Charles Croonenbergh, "Christian Worship," in Diaries of the Jesuit Missionaries at Bulawayo, 26-30, here 26.

50 Charles Croonenbergh, "Other Missionaries and Traders," in Diaries of the Jesuit Missionaries at Bulawayo, 39-42, here 40.

$51 \quad$ Ibid., 54 . 
Evidently, he did not want to antagonize the Catholic missionary by contesting the foundations of priestly celibacy.

Another case that reveals the willingness of Protestants to collaborate with Catholics, which took place at Driefontein (in Mpumalanga Province, South Africa), on Tuesday, April 13, 1915, involved a man who was dying at a mine hospital. A Protestant missionary arrived at the hospital by train and saw the patient, who asked for a Catholic priest. The Protestant set off at once, though it was already dark, to look for a priest, covering more than twenty miles on foot before arriving at the Catholic mission at 2:30 in the morning; a Catholic priest was then sent immediately to the hospital, arriving before the patient's death. The patient received the last sacraments and passed away a few hours later. The writer of the account, himself a Catholic, enthusiastically describes the non-Catholic missionary as an "angel of the Lord." 52

Another platform for collaboration between Jesuits and Protestants was the General Missionary Conference, which started in June 1914. The idea of setting up the conference was mooted in 1913 while Christians from various denominations were working together in translating the Bible. The conference boasted the membership of four Catholic orders, namely the White Fathers, the Jesuits, the Franciscans, and the Capuchin Fathers, and in the reviews and evaluations of the various participants, explicit mention is made of Jesuit participation. Reverend Sydney Douglas Gray (1883-1964), of the Wesleyan Methodists, for instance, mentions John Spendel (1880-1945) and Joseph Moreau (1864-1949), both Jesuits, who made an impression on him for their inspiring lives. Gray even reported that the devotional paper Spendel read at the conference "might have been written by a good Methodist." ${ }^{33}$ The conference was an occasion for various missionary groups to overcome prejudices and to appreciate their common humanity and Christian faith. It was remarked, for example, that these missionaries, Protestant and Catholic alike, "all met on a common level, comparing notes with each other, chatting over meals or round the camp fires, and becoming friends. Some were surprised to discover so much goodness in those they had hitherto considered bitter enemies." 54

\section{Recognition of Protestant Missionary Ability}

Early Jesuit missionaries in southern Africa knew how to give credit where it was due. And this was the case with their interaction with Protestant missionaries, some of whom exuded exceptional talents in the spheres of language

$5^{2}$ "Notes from the Different Stations," ZMR 5, no. 69 (1915): 226-33, here 229-30.

53 Cited in Peter Bolink, Towards Church Union in Zambia (Franeker: T. Wever, 1967), 133.

54 Ibid. 
and relations with local communities. Livingstone, for instance, is universally said to have won the friendship and loyalty of African peoples, both kings and subjects. When he died, his porters not only made an inventory of all the things that belonged to the traveler but also traveled a thousand miles to deliver the body (together with all his possessions) to the Englishmen who came to meet them at Unyanyembe. Contemplating Livingstone's exploits, Weld writes that "it is impossible to read these things without a deep pang of regret that Catholic missioners had not the opportunity of gaining that influence over these people which was accorded so willingly to a passing traveller. Livingstone is full of praise of the intelligence and fidelity of this people." 55

Weld also gives credit to Moffat for "the really great work of translating the Bible into the Sichuana,"56 the local language of the area. Similarly, Berghegge describes François Coillard (1834-1904), a French Protestant missionary, as a "complete master of the [local] language." Coillard taught the Africans psalms, which the natives sang, albeit imperfectly, at beer parties long after Coillard had left. ${ }^{57}$

\section{Conclusion}

It is a truism that history is often written from a particular standpoint, one that is not insulated from the thinking of the time and the exigencies of sectarian interest. Ideologies and interests partly determine the selection of data. The Second Vatican Council (1962-65), with its new vision of the relationship between the Catholic Church and other churches, marks an important watershed in the appreciation of the history of the interaction between Catholic and Protestant missionaries. The premium the council placed on ecumenism and interreligious dialogue is an invitation to re-read the history of missionary work in Africa - and the world over-in order to scout for fragments of mutual esteem and collaboration between Catholics and Protestants. Such insights would serve as precedents and lessons for strengthening the collaboration among different churches. This essay has used accounts from the nineteenth and twentieth centuries in order to paint a more accurate picture of the Jesuit estimation of the Protestant contribution to the evangelization of the peoples of southern Africa. Generally, Jesuits who interacted with Protestants

\footnotetext{
55 Weld, Mission of the Zambezi, 17, 38-39.

56 Ibid., 24 .

57 See Berghegge, "Account of a Journey in Central Africa," 7.
} 
more closely (dialogue of life) had many more good things to say about nonCatholic missionaries than has often been assumed.

\section{Bibliography}

Berghegge, Fien. "Account of a Journey in Central Africa." Rhodesiana 3 (1958): 1-13.

Bolink, Peter. Towards Church Union in Zambia. Franeker: T. Wever, 1967.

Burrett, Rob S. "The Zambezi Mission and the Residences of Good Hope and Immaculate Heart of Mary, Old Tati." Botswana Notes and Records 32 (2000): 25-38.

Carmody, Brendan. Conversion and Jesuit Schooling in Zambia. Leiden, New York, and Cologne: Brill, 1992.

Clinton, Iris. Hope Fountain Story. Bulawayo: Mambo Press, 1969.

Dachs, Anthony J., and William F. Rea. The Catholic Church and Zimbabwe. Gwelo: Mambo Press, 1979.

Diaries of the Jesuit Missionaries at Bulawayo 1879-1881. Rhodesiana Society 4. Bulawayo: Mardon Printers, 1974.

K. "On the Character of Jesuit Missionary Teaching." Church Missionary Intelligencer and Record (July 1886): 529-45.

K. "The Pope and Romish Missions." Church Missionary Intelligencer and Record (October 1886): $721-35$.

Larmer, Miles. "History of Zambia: 1902-1924." In A History of Jesuits in Zambia: A Mission Becomes a Province, edited by Edward P. Murphy, 115-41. Nairobi: Paulines Publications Africa, 2003.

Murphy, Edward, ed. Early Days of the Jesuit Zambesi Mission, 1880-19oo: Accounts by John Weisskopf and Francis Richartz. Harare: Jesuit Province of ZimbabweMozambique, 2015.

Padberg, John W., ed. Jesuit Life \& Mission Today: The Decrees \& Accompanying Documents of 3ist-35th General Congregations of the Society of Jesus. St. Louis: Institute of Jesuit Sources, 2009.

Rea, William Francis. "Rhodesian Pioneer." Rhodesiana 5 (1960): 54-59.

Sykes, Richard. "On Creating a Religious Atmosphere." ZMR 5, no. 70 (1915): 272-76.

Sykes, Richard. "Kikuyu from a Missionary's Point of View." ZMR 5, no. 65 (1914): 99-102.

Sykes, Richard. "Protestant Missionary Activity in South and Central Africa," ZMR 1, no. 1 (1898):11-15.

Sykes, Richard. "The Missioner's Debt." ZMR 5, no. 63 (1914):15-19.

Weld, Alfred. "From the Dark Continent." Tablet (December 31, 1887): 35 .

Weld, Alfred. Mission of the Zambezi. London: Burns and Oates, 1879.

Williams, Norman Powell. The Kikuyu Opinion. London: Longmans, Green and Co., 1915 . 